\title{
Microsporidia parasites disrupt the responses to cadmium exposure in a gammarid
}

\author{
Eric Gismondi ${ }^{\mathrm{a}, *}$, Thierry Rigaud ${ }^{\mathrm{b}}$, Jean-Nicolas Beisel ${ }^{\mathrm{a}}$, Carole Cossu-Leguille ${ }^{\mathrm{a}}$ \\ a Laboratoire des Interactions Ecotoxicologie Biodiversité Ecosystèmes (LIEBE), Université Paul Verlaine - METZ, CNRS UMR 7146, Campus Bridoux, \\ Avenue du Général Delestraint, 57070 Metz, France \\ ${ }^{\mathrm{b}}$ Equipe Ecologie Evolutive, UMR CNRS 5561, Biogeosciences, Université de Bourgogne, 6 Boulevard Gabriel, 21000 DIJON, France
}

\section{A R T I C L E I N F O}

\section{Article history:}

Received 23 March 2011

Received in revised form 1 August 2011

Accepted 14 September 2011

\section{Keywords:}

Gammarus roeseli

Microsporidian parasites

Biomarkers

Confounding factor

Cadmium stress

\begin{abstract}
A B S T R A C T
Microsporidia parasites are commonly found in amphipods, where they are often asymptomatic, vertically-transmitted and have several effects on host sexuality and behaviour. As amphipods are often used as models in ecotoxicological studies, we investigated the effect of microsporidian infections on energy reserves and defence capacities of Gammarus roeseli under cadmium stress. Only females were infected by two microsporidia parasites: Dictyocoela roeselum or Dictyocoela muelleri. In physiological conditions, microsporidia had no major effect on energy reserves and defence capacities of G. roeseli, while under cadmium exposure, energy reserves and antioxidant defence were weaker in infected females. Moreover, higher malondialdehyde levels detected in infected females revealed that they suffered more cellular damages. Our results suggest that microsporidia may affect gammarid fitness in stressful conditions, when parasitic stress cannot be compensated by the host. Consequently, microsporidia parasites should be a factor necessary to take into account in ecotoxicology studies involving amphipods.
\end{abstract}

(c) 2011 Elsevier Ltd. All rights reserved.

\section{Introduction}

Numerous studies have highlighted the confounding effect of parasites on the physiology of infected freshwater hosts such as bivalves (Minguez et al., 2009), arthropods (McCahon et al., 1991; Pascoe et al., 1995; Sures et al., 2002; Prenter et al., 2004; Sures, 2004), or fish (Sures et al., 2005). Parasites can either disrupt the detoxification capacity of the hosts (Sures and Radszuweit, 2007) or, conversely, can help the host detoxify by accumulating heavy metals in their own tissues (review in Sures et al., 1999).

Gammarid amphipods are increasingly used in ecotoxicological studies in both freshwater and marine environments, due to their important ecological role in the trophic chain (Forrow and Maltby, 2000). Although several biomarkers have been developed in gammarids (Geffard et al., 2007; Timofeyev et al., 2006, 2008; Guerlet et al., 2008), most studies ignore the possible effect of the presence of parasites like micro-parasites belonging to the Microspora phylum, which infect several amphipods species (Terry et al., 2004).

Microsporidia are obligate intracellular parasites closely related to fungi (Mathis, 2000) but lacking mitochondria. They therefore

\footnotetext{
* Corresponding author.

E-mail address: eric.gismondi@hotmail.fr (E. Gismondi).
}

take their energy from the host (Wittner and Weiss, 1999). Their life-cycle may use horizontal transmission (trophic transmission) and/or vertical transmission from mothers to offspring (Dunn and Smith, 2001). In gammarids, numerous microsporidia are transmitted vertically, and primarily infect ovaries and eggs (Terry et al., 2004). Different microsporidian species disrupt the normal sex differentiation in gammarids. They reverse genetic males into phenotypic functional females (Rodgers-Gray et al., 2004), which induces female-biased sex-ratios in host population (e.g. Haine et al., 2004). By increasing the number of females, verticallytransmitted microsporidia are able to maintain and spread within host populations (Bandi et al., 2001). Because they are asymptomatic and do not induce severe disease in their hosts, these microsporidia are "hidden" for observers and are often neglected during ecological or physiological studies about amphipods.

The aim of this study is to investigate if the presence of these vertically-transmitted microsporidia parasites could influence host responses to the stress induced by pollutants, therefore inducing variations in this response within the population, a phenomenon that would be a confounding factor in ecotoxicological studies. More precisely, we tested whether microsporidia could help the host to cope with stress, or conversely, if they increase the sensitivity of their hosts by causing a further weakening. The first hypothesis is based on the fact that vertically-transmitted 
microsporidia exhibit low virulence in amphipods (i.e. have a low impact on host survival and fecundity, reviewed in Dunn and Smith, 2001), and may even show beneficial effects on breeding and survival, (Haine et al., 2004, 2007; Mautner et al., 2007). Theory predicts that vertically-transmitted parasites can evolve towards low virulence (Ebert and Herre, 1996), and can even develop traits favouring their host's fitness. A trait that helps the host cope with various stresses could therefore have been selected. Nevertheless, such mutualism would be surprising in microsporidia because they are far from being neutral to their host physiology. As stated before, they entirely depend on their host for energy. In addition, the propagation of microsporidian infection within the host relies on a traumatic process, i.e. spore germination. The polar filament of the spore pierces the host cell membrane and allows the injection of the sporoplasm into a new cell (Wittner and Weiss, 1999). These obvious costs could be lowered by host compensation in nonstressful environmental conditions, as in other host-parasite systems (e.g. Barber et al., 2008). However, in stressful conditions, the host may be unable to compensate for that cost and related symptoms could appear. That is the alternative hypothesis tested in the present study, the source of stress being exposure to pollutants.

Our hypotheses were tested in Gammarus roeseli a widespread amphipod which serves as an intermediate or final host for several parasites, microsporidia included. In addition to inducing sex ratio biases, three vertically-transmitted microsporidia species, namely Nosema granulosis, Dictyocoela muelleri and Dictyocoela roeselum can influence the life history traits of $G$. roeseli by favouring survival of the young and inducing an earlier breeding in the reproductive season, respectively (Haine et al., 2004, 2007). Their prevalence can reach $60 \%$ in females, but only $0-10 \%$ in males (Haine et al., 2004). G. roeseli populations therefore harbour a mix of infected and uninfected individuals, and infection among populations also varied (Haine et al., 2004). We first analysed the prevalence of microsporidia in a $G$. roeseli population. Then we determined, in laboratory conditions, the effects of these parasites on energy reserves and antitoxic defence capacities of the host under cadmium stress.

Antitoxic defences were assayed by measuring concentrations of reduced glutathione (GSH), a tripeptide that play an essential role in the detoxification system by scavenging organic or metallic xenobiotics thanks to its thiol group (Vasseur and Leguille, 2004), as well as concentrations of metallothioneins (MT) which are involved in binding metallic compounds and contribute to protecting tissues against oxidative damage (Roesijadi, 1992; Bigot et al., 2010). In parallel, the activity of $\gamma$-glutamylcysteine ligase (GCL, EC 6.3.2.2), the enzyme which limits the de novo synthesis of glutathione, and the level of malondialdehyde (MDA), product of the lipoperoxidation considered as a biomarker of toxic effect, were also measured. Moreover, energy reserves were estimated by measuring protein concentrations as well as total lipid and glycogen contents. The levels of glycogen are representative of the energy available for current activities (Sparkes et al., 1996) whereas lipids are stored in fat bodies and are used during starvation or reproduction periods (Cargill et al., 1985).

\section{Material and methods}

\subsection{Measurement of microsporidia prevalence in G. roeseli}

Male and female $G$. roeseli were collected using pond nets and artificial traps in the Nied River (Rémilly, North-eastern France, $49^{\circ} 00^{\prime} \mathrm{N}$ and $6^{\circ} 23^{\prime} \mathrm{E}$ ) in April, July, October and December 2010. Gammarids were transferred to the laboratory in large containers filled with river water. The gonadal tissues of each gammarid were dissected and stored at $-80^{\circ} \mathrm{C}$ awaiting DNA extraction.

After DNA extraction from the gonads, the infection status of each $G$. roeseli individual (i.e. presence or absence of microsporidia) was determined using a PCRrestriction fragment length polymorphism (PCR-RFLP) method. DNA extraction and
PCR reactions were conducted as described in Haine et al. (2004). The PCR products were digested by four restriction enzymes VspI, Bst1107I, Esp3I and BglII, following the manufacturer's instructions (MBI Fermentas) in order to identify four different microsporidia species potentially infecting $G$. roeseli: D. muelleri, D. roeselum, Dictyocoela berillonum and N. granulosis, respectively.

2.2. Sensitivity of $G$. roeseli to cadmium depending on the presence/absence of microsporidia

In a preliminary experiment, the cadmium concentration that caused the death of $50 \% \mathrm{G}$. roeseli females (lethal concentration $50, \mathrm{LC}_{50}$ ) within $96 \mathrm{~h}$ was determined to be around $107 \mu \mathrm{g} \mathrm{Cd} \mathrm{L^{-1 }}$ at $15^{\circ} \mathrm{C}$. The cadmium concentration in the French Nied River is $0.2 \mu \mathrm{g} \mathrm{Cd} \mathrm{L} \mathrm{L}^{-1}$ and the maximum admissible cadmium concentration is $5 \mu \mathrm{g} \mathrm{L}^{-1}$ (LADROME laboratory, Valence, France); therefore two environmentally relevant cadmium concentrations were chosen in between these 3 values for the experimental exposures: 0 (control), 2 and $8 \mu \mathrm{g} \mathrm{L}^{-1}$. Exposure solutions were prepared using Elendt M4 modified solution with addition of $12 \mathrm{mg} \mathrm{Cd} \mathrm{L}^{-1}$ stock solution.

\subsubsection{Sample preparation}

Non-gravid G. roeseli females were collected in summer 2010 as indicated above, acclimated for 5 days before being used for experimentation at $15^{\circ} \mathrm{C}$ in an Elendt M4 modified solution, and fed ad libitum with alder leaves.

Three replicates of $50 \mathrm{G}$. roeseli females each were exposed for $96 \mathrm{~h}$ at $15^{\circ} \mathrm{C}$ at the three different cadmium conditions: $0 \mu \mathrm{g} \mathrm{L}^{-1}$ (control group), $2 \mu \mathrm{g} \mathrm{L}^{-1}$ (C1 group) and $8 \mu \mathrm{g} \mathrm{L}^{-1}$ (C2 group). After exposure, each gammarid was dissected to remove the gonads which were stored at $-80{ }^{\circ} \mathrm{C}$ awaiting DNA extraction. Microsporidia infection status (i.e. uninfected, infected by $D$. roeselum or $D$. muelleri) was determined using the PCR-RFLP method (see above). Assaying antitoxic defences is impossible to perform on individual gammarids, so a minimum number of six gammarids was necessary to have enough tissues to analyse. Therefore, for each exposure condition, three replicates of six individuals with the same microsporidian status were made to measure energy reserves and antitoxic defences as described below. The prevalence of $D$. muelleri was relatively low in this sampling, so we were unable to run metallothionein assays for this infection status.

Each replicate was homogenized with a manual Potter Elvejhem tissue grinder in $50 \mathrm{mM}$ phosphate buffer $\mathrm{KH}_{2} \mathrm{PO}_{4} / \mathrm{K}_{2} \mathrm{HPO}_{4}(\mathrm{pH}$ 7.6) supplemented with $1 \mathrm{mM}$ phenylmethylsulphonylfluoride (PMSF), and $1 \mathrm{mM}$ L-serine-borate mixture as proteases inhibitors and $5 \mathrm{mM}$ phenylglyoxal as a $\gamma$-glutamyl transpeptidase inhibitor. The homogenization buffer was adjusted at a volume two fold the wet weight of the sample pool (e.g. $400 \mu \mathrm{L}$ of homogenization buffer for $200 \mathrm{mg}$ of wet weight tissue). The homogenate was divided into five parts to measure the different parameters. For each replicate, two independent measures were made for each biomarker.

\subsubsection{Biomarker measurement}

2.2.2.1. Energy reserves. Measures of lipid and glycogen contents were adapted from Plaistow et al. (2001). Twenty microlitres of $2 \%$ sodium sulphate $(\mathrm{w} / \mathrm{v})$ and $540 \mu \mathrm{L}$ of chloroform/methanol 1:2(v/v) were added to $40 \mu \mathrm{L}$ of the total homogenate. After $1 \mathrm{~h}$ in ice, the samples were centrifuged at $3000 \times \mathrm{g}$ for $5 \mathrm{~min}$ at $4{ }^{\circ} \mathrm{C}$. The resulting supernatant was used to determine the lipid content and the pellet was used to measure the glycogen content. One hundred microlitres of supernatant were transferred to clean culture tubes and placed in a dry bath at $95{ }^{\circ} \mathrm{C}$ to evaporate the solvent. Then, $200 \mu \mathrm{L}$ of $95 \%$ sulphuric acid were added and left for $10 \mathrm{~min}$ at $95^{\circ} \mathrm{C}$. The different tubes were removed and cooled in ice, and then $4.8 \mathrm{~mL}$ of phosphovanillin reagent were added. After a 10 -min reaction time, the optical density was measured at $535 \mathrm{~nm}$ using cholesterol as standard. The total lipid contents were expressed in $\mathrm{mg} \mathrm{mL}^{-1}$. The pellet was dissolved in $400 \mu \mathrm{L}$ of deionised water and $100 \mu \mathrm{L}$ of sample were placed into clean culture tubes supplemented with $4.9 \mathrm{~mL}$ of Anthrone reagent, boiled in a dry bath at $95^{\circ} \mathrm{C}$ for $17 \mathrm{~min}$, and cooled in ice. Then, the optical density was measured at $625 \mathrm{~nm}$ using glucose as a standard. Glycogen concentrations were expressed in $\mu \mathrm{g} \mathrm{mg}^{-1}$ tissue.

The total protein content of each sample was quantified as described in Bradford (1976) with bovine serum albumin (BSA) as a standard. The results were expressed in $\mathrm{mg} \mathrm{mL}^{-1}$.

\subsubsection{Antitoxic defences capacities}

Reduced glutathione (GSH) concentration was assessed by High-Pressure Liquid Chromatography (HPLC) separation adapted from Leroy et al. (1993). The proteins contained in $40 \mu \mathrm{L}$ of the total homogenate were precipitated with $10 \%$ perchloric acid (v/v). After a 10 min-centrifugation at $20000 \times g$ and $4{ }^{\circ} \mathrm{C}$, the resulting supernatant was diluted 40 -fold in $0.1 \mathrm{M} \mathrm{HCl}$. Commercial GSH diluted in $0.1 \mathrm{M} \mathrm{HCl}$ was used as a standard. GSH concentrations were expressed in nmol GSH mg ${ }^{-1}$ protein.

The $\gamma$-glutamylcysteine ligase (GCL) activity was assayed using an HPLC method adapted from Parmentier et al. (1998). Measurements were carried out on the S12000 fraction obtained after centrifuging $40 \mu \mathrm{L}$ of the total homogenate for $15 \mathrm{~min}$ at $500 \times g$ and then centrifuging the resulting supernatant at $12,000 \times g$ and $4{ }^{\circ} \mathrm{C}$ for $30 \mathrm{~min}$. A forty-fold dilution of the $\mathrm{S} 12000$ supernatant was prepared in the homogenization buffer and forty microlitres of this diluted solution were added to $112 \mu \mathrm{L}$ of incubation cocktail $\left(0.5 \mathrm{M}\right.$ Tris $\mathrm{HCl}, 200 \mathrm{mM} \mathrm{MgCl} 26 \mathrm{H}_{2} \mathrm{O}, 500 \mathrm{mM} \mathrm{KCl}$, $45 \mathrm{mM}$ glutamic acid, $90 \mathrm{mM}$ cystein, $1 \mathrm{mM}$ DTT, $90 \mathrm{mM}$ ATP, $0.5 \mathrm{mM}$ phenylglyoxal, 
$\mathrm{pH} 8.25)$ in a $1.5 \mathrm{~mL}$ tube to initiate the reaction. The mixture was incubated for $20 \mathrm{~min}$ in a water bath at $25^{\circ} \mathrm{C}$ and the reaction was stopped by a four-fold dilution with $0.1 \mathrm{M} \mathrm{HCl}$. Commercial glutamylcysteine (GC) solution prepared in $0.1 \mathrm{M} \mathrm{HCl}$ was used as a standard and GCL activity was expressed in $\mathrm{nmol} \mathrm{GC} \mathrm{min}^{-1} \mathrm{mg}^{-1}$ protein.

Metallothionein (MT) concentrations were determined with an HPLC method adapted from Alhama et al. (2006). Forty microlitres of the total homogenate were centrifuged at $3500 \times g$. The resulting supernatant was centrifuged at $22,000 \times g$ and $4{ }^{\circ} \mathrm{C}$ to obtain the $\mathrm{S} 22000$ fraction. A ten-fold dilution of the $\mathrm{S} 22000$ fraction was prepared in $100 \mathrm{mM}$ Tris buffer ( $\mathrm{pH}$ 9.5) supplemented with $1 \mathrm{mM}$ DTT and $100 \mathrm{mM}$ PMSF as a protease inhibitor. To reduce and denature the protein, $125 \mu \mathrm{L}$ of diluted sample were added to $108 \mu \mathrm{L}$ of incubation cocktail (230 mM Tris pH 9.5, $300 \mathrm{mM}$ DTT, $100 \mathrm{mM}$ EDTA and $10 \%$ sodium dodecyl sulphate) in a water bath at $70{ }^{\circ} \mathrm{C}$ for $20 \mathrm{~min}$. Then, the incubation mixture was supplemented with $17 \mu \mathrm{L}$ of $180 \mathrm{mM}$ monobromobimane $(\mathrm{mBBr})$ and incubated in the dark at room temperature for $15 \mathrm{~min}$, to mark MTs. Commercial rabbit-liver MT I solution prepared in $230 \mathrm{mM}$ Tris, pH 9.5, was used as a standard and MT concentrations were expressed in nmol MT $\mathrm{mg}^{-1}$ protein.

\subsubsection{Biomarker of toxic effect}

Malondialdehyde (MDA) levels were determined using an HPLC method adapted from Behrens and Madère (1991) with UV detection at $267 \mathrm{~nm}$. Seventy microlitres of the total homogenate were diluted four-fold in 95\% ethanol (HPLC grade) and cooled on ice for $1.5 \mathrm{~h}$ to deproteinize them. The mixture was then centrifuged at $18,000 \times g$ for $30 \mathrm{~min}$ at $4{ }^{\circ} \mathrm{C}$. One hundred microlitres of the resulting supernatant was injected into the HPLC separation system. MDA levels were expressed in ng MDA $\mathrm{mg}^{-1}$ lipid.

\subsection{Statistical analysis}

Our data were analysed by using a multivariate analysis of variance (MANOVA, Pillai's trace) with respect to "infection status" and "cadmium concentration" as fixed factors. Since the MANOVA test was significant, each biomarker was then analysed using ANOVA tests, followed by TukeyHSD post-hoc tests.

The tests were performed using R 2.9.0 and JMP v5.0 (SAS Institute, Cary, USA) and were two-tailed with significant differences considered at the level of $P \leq 0.05$.

\section{Results}

\subsection{Microsporidia species and prevalence in $\mathrm{G}$. roeseli}

Two microsporidia species, $D$. muelleri and $D$. roeselum were identified using PCR-RFLP method (Table 1).

Whatever the season, only females were infected by microsporidia. In spring, the proportion of infected G. roeseli females was the highest (77.7\%). In the others seasons, the proportion was about $40 \%$ (Likelihood-Ratio $\chi^{2}=34.74,3$ d.f., $P<0.0001$ ). The most abundant microsporidia species found in females was $D$. roeselum, which averaged $70 \%$ of infected females whatever the season. No female was found co-infected by both parasite species.

\subsection{Effects of microsporidia without cadmium exposure}

As shown in the figures and the post-hoc tests, the infection by microsporidia rarely had an effect on the tested biomarkers (see the

Table 1

Table of microsporidia prevalence according to the season and to G. roeseli gender.

\begin{tabular}{|c|c|c|c|c|}
\hline & $\begin{array}{l}\text { G. roeseli } \\
\text { genders }(N)\end{array}$ & $\begin{array}{l}\text { Infected } \\
(N)\end{array}$ & Microsporidia species & $\begin{array}{l}\text { Prevalence } \\
(N)\end{array}$ \\
\hline \multirow[t]{3}{*}{ Spring } & Females (166) & $77.7 \%(129)$ & Dictyocoela roeselum & $67.4 \%(87)$ \\
\hline & & & Dictyocoela muelleri & $32.6 \%(42)$ \\
\hline & Males (30) & $0 \%(0)$ & - & - \\
\hline \multirow[t]{3}{*}{ Summer } & Females (124) & $41.9 \%(52)$ & Dictyocoela roeselum & $73.1 \%(38)$ \\
\hline & & & Dictyocoela muelleri & $26.9 \%(14)$ \\
\hline & Males (34) & $0 \%(0)$ & - & - \\
\hline \multirow[t]{3}{*}{ Autumn } & Females (95) & $40 \%(38)$ & Dictyocoela roeselum & $65.8 \%(25)$ \\
\hline & & & Dictyocoela muelleri & $34.2 \%(13)$ \\
\hline & Males (20) & $0 \%(0)$ & - & - \\
\hline \multirow[t]{3}{*}{ Winter } & Females (102) & $45 \%(46)$ & Dictyocoela roeselum & $67.4 \%(31)$ \\
\hline & & & Dictyocoela muelleri & $32.6 \%(15)$ \\
\hline & Males (26) & $0 \%(0)$ & - & - \\
\hline
\end{tabular}

$N$ : number of individuals. control groups only in Figs. 1-3). Only the glycogen content was higher in gammarid females infected by D. roeselum (Fig. 3c).

\subsection{Microsporidian effect in $G$. roeseli after cadmium exposures}

Global MANOVA analysis revealed an effect of cadmium exposure, parasite infection, and their interactions on biomarker levels (Table 2). The results are described below in detail for each biomarker below.

\subsubsection{Toxic effect biomarker}

MDA levels, used as a toxicity biomarker, were much higher in females exposed to cadmium compared to unexposed controls, whatever the infection status (Table 2, Fig. 1). However, the infection by microsporidia parasites also influenced MDA levels significantly, and in interaction with cadmium exposure (Table 2). In uninfected females, the higher the cadmium concentration, the higher the MDA level. Indeed, it increased two fold at $2 \mu \mathrm{g} \mathrm{Cd} \mathrm{L}{ }^{-1}$ and threefold at $8 \mu \mathrm{g} \mathrm{Cd} \mathrm{L^{-1 }}$ compared to the control. This doseresponse relationship was not found in infected females, in which the MDA level already showed a threefold increase at the lowest cadmium concentration (Fig. 1). Microsporidian infection was therefore linked with a higher MDA level, only in the case of cadmium exposure.

\subsubsection{Defence capacities}

GSH concentrations and GCL activity were significantly influenced by the interaction between the infection status and cadmium contamination (Table 2). In uninfected females, GSH concentration increased after exposure to the lowest cadmium dose $\left(2 \mu \mathrm{g} \mathrm{Cd} \mathrm{L}^{-1}\right)$ compared to unexposed control females, but remained unchanged after exposure to our highest cadmium dose $\left(8 \mu \mathrm{g} \mathrm{Cd} \mathrm{L}^{-1}\right)$ (Fig. 2a). However, when females were infected by $D$. roeselum or $D$. muelleri, no significant change in GSH concentration was observed after cadmium exposure (Fig. 2a).

The pattern of change in GCL activity was similar to the one observed for GSH in uninfected females: it showed an increase at the lowest cadmium exposure (Fig. 2b). No major significant difference was observed in GCL activity in $D$. roeselum-infected females. Contrastingly, females infected by $D$. muelleri showed a significantly increased GCL activity after cadmium exposure, whatever the cadmium concentration (Fig. 2b).

Metallothionein concentrations were only measured in uninfected and $D$. roeselum-infected females due to the lack of females

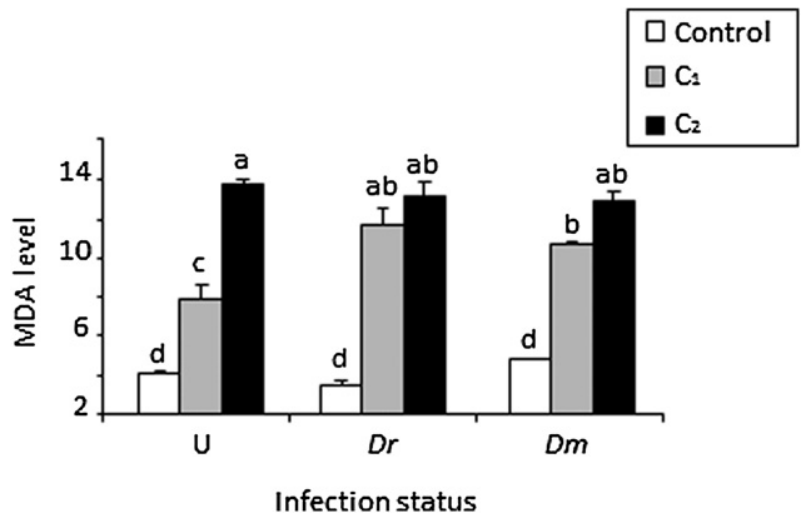

Fig. 1. Influence of the presence of microsporidia parasite on the malondialdehyde level of Gammarus roeseli females exposed to $\mathrm{CdCl}_{2}$ for $96 \mathrm{~h}$. U: uninfected, Dr: Dictyocoela roeselum-infected females, Dm: Dictyocoela muelleri-infected females, $\mathrm{C}_{1}$ : $2 \mu \mathrm{g} \mathrm{Cd} \mathrm{L}{ }^{-1}, C_{2}: 8 \mu \mathrm{g} \mathrm{Cd} \mathrm{L}{ }^{-1}$. Different letters above the bars indicate significantly different values (Tukey's HSD test, $P$-values $<0.05$ ). 

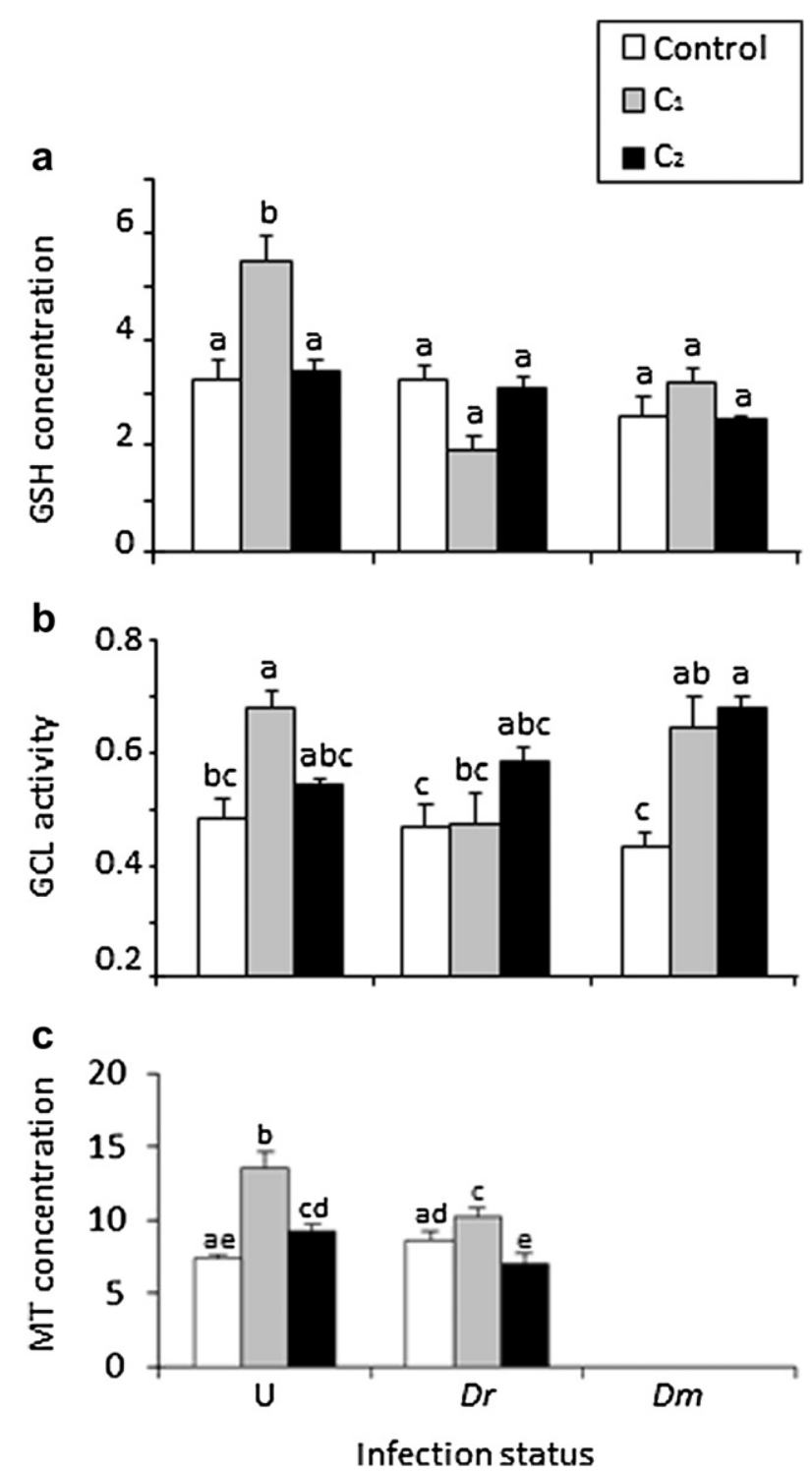

Fig. 2. Influence of the presence of microsporidia parasites on reduced glutathione concentrations (a), $\gamma$-glutamylcysteine ligase activity (b) and metallothionein concentrations (c) of Gammarus roeseli females exposed to $\mathrm{CdCl}_{2}$ for $96 \mathrm{~h}$. U: uninfected, Dr: Dictyocoela roeselum-infected females, Dm: Dictyocoela muelleri-infected

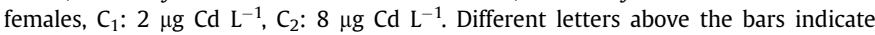
significantly different values (Tukey's HSD test, $P$-values $<0.05$ ).

infected by $D$. muelleri. Univariate analysis of variance (ANOVA) highlighted that the variation in MT concentration was influenced by the interaction between microsporidia presence and cadmium exposure (Table 3). In uninfected females, MT showed a significant increase at the two cadmium concentrations, whereas in $D$. roeseluminfected females, a significant increase was observed at $2 \mu \mathrm{g} \mathrm{Cd} \mathrm{L}^{-1}$ and a significant decrease at $8 \mu \mathrm{g} \mathrm{Cd} \mathrm{L}^{-1}$ (Fig. 2c).

\subsubsection{Energy reserves}

Proteins, lipids and glycogen levels were significantly influenced by the interaction between the infection status and cadmium exposure (Table 2). However the significance was marginal for proteins. Protein concentrations remained globally unchanged after cadmium exposure; except for $D$. muelleri-infected females which appeared to have a lower protein concentration after exposure compared to their respective control (Fig. 3a).
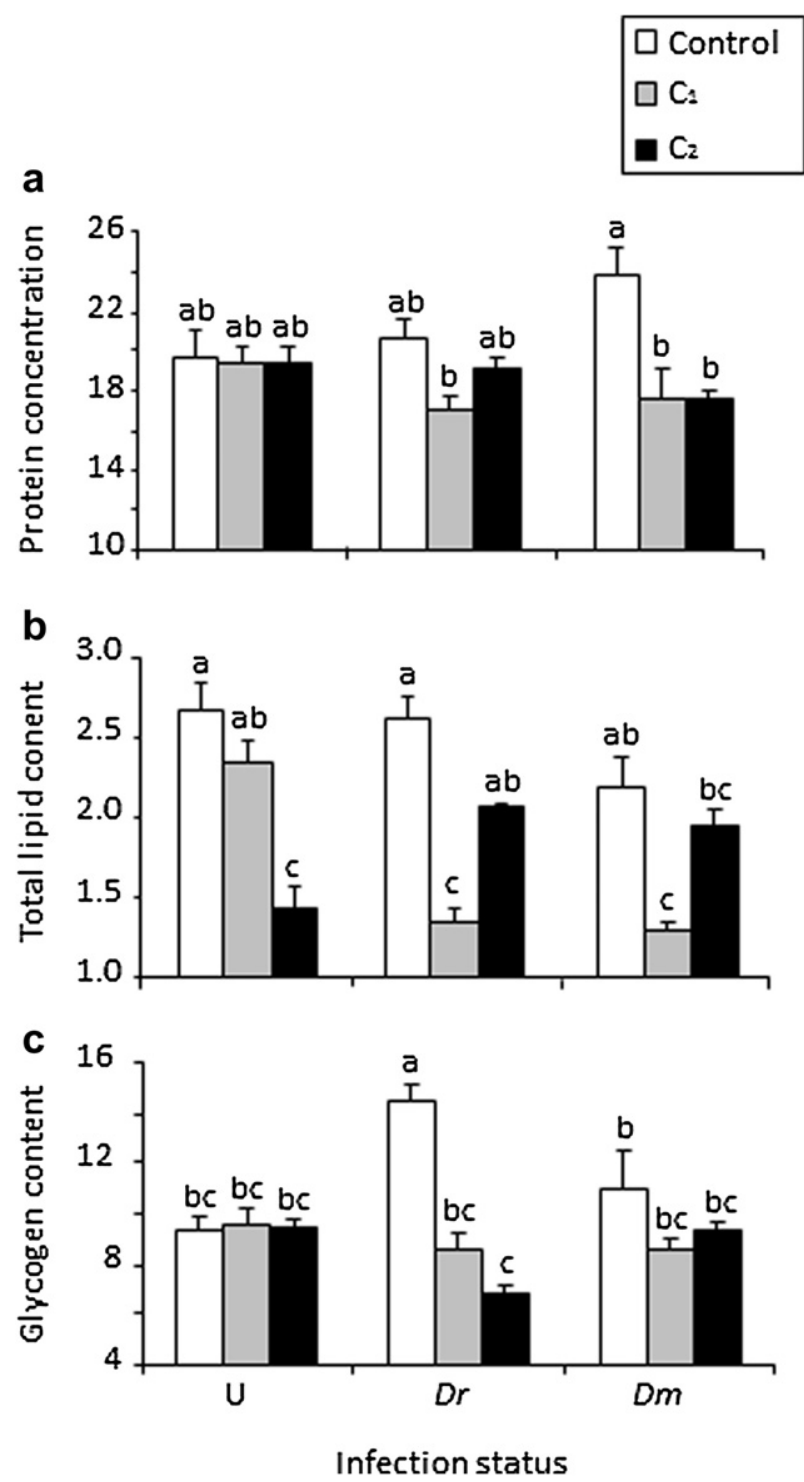

Fig. 3. Influence of the presence of microsporidia parasites on the protein concentrations (a), total lipid (b) and glycogen (c) contents of Gammarus roeseli females exposed to $\mathrm{CdCl}_{2}$ for $96 \mathrm{~h}$. U: uninfected, Dr: Dictyocoela roeselum-infected females,

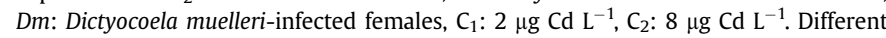
letters above the bars indicate significantly different values (Tukey's HSD test, $P$-values $<0.05$ ).

Uninfected females showed a significant decrease in total lipid contents only after the highest cadmium exposure (Fig. 3b). Contrastingly, this dose-response relationship was not found in females infected by the two parasite species, among which the decrease in lipid content was only measured at $2 \mu \mathrm{g} \mathrm{Cd} \mathrm{L}^{-1}$ (Fig. 3b). In fact, the total lipid content was reduced by half in the presence of $D$. muelleri and divided by three when $D$. roeselum was present compared to their respective controls.

The glycogen content of uninfected females and D. muelleriinfected females was not impacted by cadmium exposure, but it decreased by an average $50 \%$ in $D$. roeselum-infected females whatever the cadmium concentration (Fig. 3c).

\section{Discussion}

This study was carried out to understand the influence of the presence of parasites in an ecotoxicological context by studying the 
Table 2

Multivariate (Pillai's trace) and univariate analyses of variance investigating variations in biomarkers for toxicity (MDA), defence capacity (GSH, GCL) and energy reserves (protein, lipid, glycogen) of Gammarus roeseli, according to the infection by microsporidian parasites, and cadmium contamination.

\begin{tabular}{|c|c|c|c|c|c|}
\hline Models & Parameter & Source of variation & $\begin{array}{l}\text { num d.f. }{ }^{\mathrm{a}} \text {, } \\
\text { den d.f. }{ }^{\mathrm{b}}\end{array}$ & $F$ & $P$ \\
\hline \multirow[t]{4}{*}{ MANOVA } & & Whole model & 48,108 & 5.98 & $<0.0001$ \\
\hline & & Infection status & 12,28 & 5.46 & 0.0001 \\
\hline & & Cadmium exposure & 12,28 & 12.28 & $<0.0001$ \\
\hline & & Infection:Cadmium & 24,64 & 4.75 & $<0.0001$ \\
\hline \multirow[t]{24}{*}{ ANOVAs } & MDA & Whole model & 8,18 & 68.80 & $<0.0001$ \\
\hline & & Infection status & 2,18 & 3.12 & $<0.0001$ \\
\hline & & Cadmium exposure & 2,18 & 257.22 & $<0.0001$ \\
\hline & & Infection:Cadmium & 4,18 & 7.43 & 0.0010 \\
\hline & GSH & Whole model & 8,18 & 11.00 & $<0.0001$ \\
\hline & & Infection status & 2,18 & 18.89 & $<0.0001$ \\
\hline & & Cadmium exposure & 2,18 & 3.16 & 0.0666 \\
\hline & & Infection:Cadmium & 4,18 & 10.98 & 0.0001 \\
\hline & GCL & Whole model & 8,18 & 7.82 & 0.0002 \\
\hline & & Infection status & 2,18 & 4.32 & 0.0294 \\
\hline & & Cadmium exposure & 2,18 & 16.25 & $<0.0001$ \\
\hline & & Infection:Cadmium & 4,18 & 5.35 & 0.0051 \\
\hline & Proteins & Whole model & 8,18 & 3.66 & 0.0105 \\
\hline & & Infection status & 2,18 & 0.38 & 0.6882 \\
\hline & & Cadmium exposure & 2,18 & 8.63 & 0.0024 \\
\hline & & Infection:Cadmium & 4,18 & 2.83 & 0.0556 \\
\hline & Total lipids & Whole model & 8,18 & 16.05 & $<0.0001$ \\
\hline & & Infection status & 2,18 & 4.87 & 0.0204 \\
\hline & & Cadmium exposure & 2,18 & 33.59 & $<0.0001$ \\
\hline & & Infection:Cadmium & 4,18 & 12.88 & $<0.0001$ \\
\hline & Glycogen & Whole model & 8,18 & 9.85 & $<0.0001$ \\
\hline & & Infection status & 2,18 & 0.37 & 0.6935 \\
\hline & & Cadmium exposure & 2,18 & 18.25 & $<0.0001$ \\
\hline & & Infection:Cadmium & 4,18 & 10.38 & 0.0002 \\
\hline
\end{tabular}

effect of the presence of intracellular, vertically-transmitted microsporidia in the amphipod $G$. roeseli. Indeed, while macroparasites have already been shown to decrease significantly the degree of accumulation of heavy metals in their hosts (Siddall and Sures, 1998; Sures and Radszuweit, 2007; Sures and Taraschewski, 1995), the effect of micro-parasites on the response to toxics has remained quite overlooked so far.

\subsection{Prevalence and identification of microsporidia}

No G. roeseli male was found infected, whereas females were infected by two microsporidia species: $D$. roeselum and $D$. muelleri. Our results are in line with those of Haine et al. (2004) who found these two species in two populations of G. roeseli in Burgundy (France), and demonstrated that they were vertically-transmitted. However, a third parasite identified in Burgundy, N. granulosis (Haine et al., 2004) was not found in our study. The prevalence of these two Dictyocoela species was found to vary among populations (Haine et al., 2004) but in our study D. roeselum dominated regardless of the season. The fact that only females were infected by

Table 3

Univariate analysis of variance investigating variations in MT concentration in Gammarus roeseli, according to the infection by microsporidian parasites, and cadmium contamination.

\begin{tabular}{lllll}
\hline Source of variation & Sum of squares & d.f. & $F$ & $P$ \\
\hline Infection status & 15.05 & 1 & 30.00 & $<\mathbf{0 . 0 0 0 1}$ \\
Cadmium exposure & 97.54 & 2 & 97.18 & $\mathbf{< 0 . 0 0 0 1}$ \\
Infection:Cadmium & 28.48 & 2 & 28.37 & $<\mathbf{0 . 0 0 0 1}$ \\
\hline
\end{tabular}

Significant values shown in bold. microsporidia in our population confirms that these parasites are likely sex ratio distorters (Haine et al., 2004, 2007).

\subsection{Influence of the microsporidia presence in physiological conditions}

In physiological conditions (i.e. in the absence of cadmium stress), the presence of $D$. roeselum or $D$. muelleri had no or little influence on the energy reserves and antitoxic defences of $G$. roeseli females. From an evolutionary point of view, this absence of effect could be explained by the fact that vertically-transmitted microsporidia are directly depend on the survival and reproduction of their host for their own transmission. Indeed, a low virulence could lead to better survival of the host, resulting in a more successful transmission (Dunn et al., 1995; Kelly et al., 2003; Smith, 2009). For example, Terry et al. (1998) demonstrated that Gammarus duebeni survival was not affected by $N$. granulosis. Haine et al. (2007) even found a survival advantage in young infected G. roeseli. However, the absence of a negative impact on host physiology is surprising considering that microsporidia, which are amitochondrial parasites; totally rely on their host for their metabolism (Wittner and Weiss, 1999). Instead of considering that these parasites have no impact on their hosts, it is probably more reasonable to consider that the host can easily compensate for the cost related to this kind of parasitism in a physiological context. Such compensation could depend on environmental conditions, as shown in certain studies; for example, Terry et al. (1998) and Kelly et al. (2001) showed that $N$. granulosis caused a reduced egg production in G. duebeni females. In addition, in the sea amphipod Monoporeia affinis, increased microsporidia prevalence due to organic pollutant exposure was correlated to an increase in the amount of dead eggs in the gonads (Jacobson et al., 2010, 2011).

\subsection{Influence of microsporidian infection under cadmium exposure}

For all biomarkers, microsporidian infection mainly had an effect in interaction with cadmium exposure (although the significance was lower for protein contents).

Reduced glutathione concentration increased in uninfected females exposed at $2 \mu \mathrm{g} \mathrm{Cd} \mathrm{L^{-1 }}$ while it remained unchanged in infected ones. These results are in tune with other studies which show that GSH concentration can increase (Schlenk and Rice, 1998; Lange et al., 2002), remain unchanged (Thomas and Wofford, 1993) or decrease (Soussi et al., 2008) in organisms exposed to cadmium. GCL is the enzyme that limits GSH synthesis (Ray et al., 1999); therefore variations in GSH concentration should be correlated with GCL activity in stress conditions. GCL activity increased during cadmium exposure whatever the parasitic status of $G$. roeseli females, especially when infected females were exposed at $8 \mu \mathrm{g} \mathrm{Cd} \mathrm{L}{ }^{-1}$. This result is in agreement with Lee et al. (2003) who described an increase in GCL activity as well as in GSH concentration in different stress conditions. However, in our study, GSH concentration was unchanged in infected females although GCL activity increased. This could be explained by the fact that reduced glutathione could be used immediately to detoxify the organism (Meister, 1983; Singhal et al., 1987; Akira et al., 1990). In the same way, the content in metallothioneins, which are proteins that protect against cytotoxicity (Cajaraville et al., 2000), significantly increased in uninfected females whereas it only slightly increased in infected ones. This result agrees with some studies which demonstrate that cadmium induces MT synthesis in invertebrate organisms (Stuhlbacher and Maltby, 1992; Bigot et al., 2010). We can hypothesize that MT, like GSH, could be used in infected females more than in uninfected ones to fight against cadmium stress. The variations in defence capacities, found in this study, 
therefore highlight that infected gammarids could be more susceptible in an environmental contamination context. The MDA levels measured in this experiment could support this hypothesis. Indeed, MDA level increased during cadmium exposure in both uninfected and infected $G$. roeseli females, reflecting the toxic effect of cadmium. The same pattern was observed by Khan et al. (2010) who demonstrated an increase of lipoperoxidation in Gammarus pulex exposed to metal contamination, while Correia et al. (2002) and Sroda and Cossu-Leguille (2011) demonstrated an increase in MDA levels in Gammarus locusta or G. roeseli, respectively, after copper intoxication. In addition, in our study, MDA levels were higher in infected females (especially when exposed to $2 \mu \mathrm{g} \mathrm{L}^{-1}$ of cadmium) compared to uninfected ones, which confirms the hypothesis of higher toxic effects in infected G. roeseli females. Microsporidia germination may explain this higher stress in infected females. Indeed, Keeling and Fast (2002) demonstrated that various physical or chemical stimuli ( $\mathrm{pH}$ alterations, ultraviolet or peroxide exposure) could induce microsporidia spore germination which could in turn be considered by gammarid as a supplementary stress. Ford et al. (2006) observed that gammarid intersex specimens were significantly more likely to be infected with microsporidian parasites at sites receiving waste effluent rather than at reference sites; suggesting that parasitism is related to water quality. Moreover, Jacobson et al. (2011) demonstrated that there was an increase in the percentage of parasites infecting the amphipod M. affinis exposed to the antifouling agent tributyltin. It remains to be investigated whether the increased proportion of parasite-infected animals could be due to an immunotoxic effect of tributyltin or to a consequence of competition for energy between the detoxification machinery and the immune system (Jacobson et al., 2011). Thus, cadmium could induce microsporidian germination, a hypothesis which remains to be tested.

Total lipid and glycogen contents were also affected by infection during our exposure experiments. Sroda and Cossu-Leguille (2011) highlighted a decrease in total lipid and glycogen contents in G. roeseli females exposed to copper. Lee et al. (1981) also observed a decrease in lipid content in Amphithoe valida (Crustacea, Amphipoda) exposed to No. 2 fuel oil containing benzene extracted organics. Moreover, Barata et al. (2005) demonstrated a decrease in lipid content in Daphnia magna exposed to cadmium for $48 \mathrm{~h}$. In our study, total lipid decrease was more marked in infected females than in uninfected ones at the low cadmium dose. This could be explained by a consumption of host lipids by the parasite. As microsporidian parasites and their hosts share similar membrane lipids (Vivarès et al., 1980; Biderre et al., 2000), microsporidia could perhaps use host lipids to make new membranes and form new spores.

Contrasting with lipids, glycogen content remained unchanged after cadmium exposure in uninfected females, a result that confirms those of Dietrich et al. (2010) in Gammarus fossarum exposed to a pharmaceutical mixture. However, when females were infected by microsporidia species, there was a decrease in glycogen content, recalling the one described by Vivarès and Cuq (1981) in Carcinus mediterraneus (Crustacea: Decapoda) massively infected by Thelohania meanadis microsporidia. The decrease in

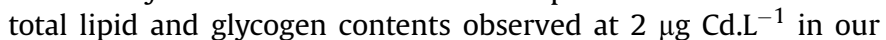
study suggests differences in their mobilization to respond to the energetic demand in a toxic environment. Glycogen may be easily catabolized to produce a rapid source of energy necessary for the organism to cope with stress (Dutra et al., 2009). On the other hand, it is well known that microsporidia are amitochondrial, so they could use host glycogen as an energy source. This hypothesis is supported by the fact that five enzymes of the glycolysis pathway were found to be significantly active and functional in Nosema spores (Méténier and Vivarès, 2001).

\section{Conclusion}

This study highlights the importance of taking into account the presence of 'unseen' (i.e. asymptomatic) microsporidia in ecotoxicological studies when using gammarids as a biological model. First, microsporidia could be a confounding factor in ecotoxicology because infected females could be more sensitive to cadmium stress. Indeed, microsporidia induce a stress that gammarids could be able to compensate for in physiological conditions but not under stress conditions. Pollution by heavy metals in addition to microsporidian infection could be described as a stress-on-stress phenomenon. Second, microsporidia infect almost half the females in G. roeseli populations, and their prevalence is variable among populations (e.g. Haine et al., 2004). Therefore, comparing the response to pollutants in two gammarid populations with unknown infection levels would probably lead to misleading results.

\section{Acknowledgements}

This study was supported by the French Ministry of Education and Research (Ministère de l'Enseignement Supérieur et de la Recherche), which we sincerely thank here. The present work was funded by the research program EC2CO (Ecosphère Continentale et Côtière). We are grateful to Annie Buchwalter for improving the English text and we wish to thank the anonymous reviewers for their helpful comments on a previous draft of this paper.

\section{References}

Akira, N., Anderson, M.E., Meister, A., 1990. Cellular glutathione as a determinant of sensitivity to mercuric chloride toxicity: prevention of toxicity by giving glutathione monoester. Biochemical Pharmacology 40, 693-697.

Alhama, J., Romero-Ruiz, A., Lopez-Barea, J., 2006. Metallothionein quantification in clams by reversed-phase high-performance liquid chromatography coupled to fluorescence detection after monobromobimane derivatization. Journal of Chromatography A 1107, 52-58.

Bandi, C., Dunn, A.M., Hurst, G.D.D., Rigaud, T., 2001. Inherited microorganisms, sexspecific virulence and reproductive parasitism. Trends in Parasitology 17, 88-94.

Barata, C., Varo, I., Navarro, J.C., Arun, S., Porte, C., 2005. Antioxidant enzyme activities and lipid peroxidation in the freshwater cladoceran Daphnia magna exposed to redox cycling compounds. Comparative Biochemistry and Physiology Part C: Toxicology and Pharmacology 140, 175-186.

Barber, I., Wright, H.A., Arnott, S.A., Wootton, R.J., 2008. Growth and energetics in the stickleback Schistocephalus host-parasite system: a review of experimental infection studies. Behaviour 145, 647-668.

Behrens, W., Madère, R., 1991. Malonaldehyde determination in tissues and biological fluids by ion-pairing high-performance liquid chromatography. Lipids 26, 232-236

Biderre, C., Babin, F., Vivarès, C.P., 2000. Fatty acid composition of four Microsporidian species compared to that of their host fishes. Journal of Eukaryotic Microbiology 47, 7-10.

Bigot, A., Minguez, L., Giambérini, L., Rodius, F., 2010. Early defense responses in the freshwater bivalve Corbicula fluminea exposed to copper and cadmium: transcriptional and histochemical studies. Environmental Toxicology. doi:10.1002/ tox.20599.

Bradford, M.M., 1976. A rapid and sensitive method for the quantitation of microgram quantities of protein utilizing the principle of protein-dye binding. Analytical Biochemistry 72, 248-254.

Cajaraville, M.P., Bebianno, M.J., Blasco, J., Porte, C., Sarasquete, C., Viarengo, A., 2000. The use of biomarkers to assess the impact of pollution in coastal environments of the Iberian Peninsula: a practical approach. The Science of the Total Environment 247, 295-311.

Cargill, A.S., Cummins, K.W., Hanson, B.J., Lowry, R.R., 1985. The role of lipids as feeding stimulants for shredding aquatic insects. Freshwater Biology 15, 455-464.

Correia, A.D., Livingstone, D.R., Costa, M.H., 2002. Effects of water-borne copper on metallothionein and lipid peroxidation in the marine amphipod Gammarus locusta. Marine Environmental Research 54, 357-360.

Dietrich, S., Dammel, S., Ploessl, F., Bracher, F., Laforsch, C., 2010. Effects of a pharmaceutical mixture at environmentally relevant concentrations on the amphipod Gammarus fossarum. Marine and Freshwater Research 61, 196-203. 
Dunn, A.M., Hatcher, M.J., Terry, R.S., Tofts, C., 1995. Evolutionary ecology of vertically transmitted parasites: transovarial transmission of a microsporidian sex ratio distorter in Gammarus duebeni. Parasitology 111 (Suppl. S1), S91-S109.

Dunn, A.M., Smith, J.E., 2001. Microsporidian life cycles and diversity: the relationship between virulence and transmission. Microbes and Infection 3, 381-388.

Dutra, B.K., Fernandes, F., Lauffer, A., Oliveira, G., 2009. Carbofuran-induced alterations in the energy metabolism and reproductive behaviors of Hyalella castroi (Crustacea, Amphipoda). Comparative Biochemistry and Physiology Part C: Toxicology and Pharmacology 149, 640-646.

Ebert, D., Herre, E.A., 1996. The evolution of parasitic diseases. Parasitology Today 12, 96-101.

Ford, A.T., Fernandes, T.F., Robinson, C.D., Davies, I.M., Read, P.A., 2006. Can industrial pollution cause intersexuality in the amphipod, Echinogammarus marinus? Marine Pollution Bulletin 53, 100-106.

Forrow, D.M., Maltby, L., 2000. Toward a mechanistic understanding of contaminant-induced changes in detritus processing in streams: direct and indirect effects on detritivore feeding. Environmental Toxicology and Chemistry $19,2100-2106$

Geffard, A., Quéau, H., Dedourge, O., Biagianti-Risboug, S., Geffard, O., 2007. Influence of biotic and abiotic factors on metallothionein level in Gammarus pulex. Comparative Biochemistry and Physiology Part C: Toxicology and Pharmacology $145,632-640$.

Guerlet, E., Ledy, K., Giambérini, L., 2008. Is the freshwater gammarid, Diker ogammarus villosus, a suitable sentinel species for the implementation of histochemical biomarkers? Chemosphere 72, 697-702.

Haine, E.R., Brondani, E., Hume, K.D., Perrot-Minnot, M., Gaillard, M., Rigaud, T., 2004. Coexistence of three microsporidia parasites in populations of the freshwater amphipod Gammarus roeseli: evidence for vertical transmission and positive effect on reproduction. International Journal for Parasitology 34 , $1137-1146$

Haine, E.R., Motreuil, S., Rigaud, T., 2007. Infection by a vertically-transmitted microsporidian parasite is associated with a female-biased sex ratio and survival advantage in the amphipod Gammarus roeseli. Parasitology 134 1363-1367.

Jacobson, T., Holmström, K., Yang, G., Ford, A.T., Berger, U., Sundelin, B., 2010. Perfluorooctane sulfonate accumulation and parasite infestation in a field population of the amphipod Monoporeia affinis after microcosm exposure. Aquatic Toxicology 98, 99-106.

Jacobson, T., Sundelin, B., Yang, G., Ford, A.T., 2011. Low dose TBT exposure decreases amphipod immunocompetence and reproductive fitness. Aquatic Toxicology 101, 72-77.

Keeling, P.J., Fast, N.M., 2002. Microsporidia: biology and evolution of highly reduced intracellular parasites. Annual Review of Microbiology 56, 93-116.

Kelly, A., Dunn, A.M., Hatcher, M.J., 2001. Population dynamics of a vertically transmitted, parasitic sex ratio distorter and its amphipod host. Oikos 94 $392-402$.

Kelly, A., Hatcher, M.J., Dunn, A.M., 2003. The impact of a vertically transmitted microsporidian, Nosema granulosis on the fitness of its Gammarus duebeni host under stressful environmental conditions. Parasitology 126, 119-124.

Khan, F.R., Bury, N.R., Hogstrand, C., 2010. Cadmium bound to metal rich granules and exoskeleton from Gammarus pulex causes increased gut lipid peroxidation in zebrafish following single dietary exposure. Aquatic Toxicology 96, 124-129.

Lange, A., Ausseil, O., Segner, H., 2002. Alterations of tissue glutathione levels and metallothionein mRNA in rainbow trout during single and combined exposure to cadmium and zinc. Comparative Biochemistry and Physiology Part C: Toxicology and Pharmacology 131, 231-243.

Lee, W.Y., Macko, S.A., Nicol, J.A.C., 1981. Changes in nesting behavior and lipid content of a marine amphipod (Amphithoe valida) to the toxicity of a no. 2 fue oil. Water, Air, and Soil Pollution 15, 185-195

Lee, Y.Y., Kim, S.J., Park, E.H., Lim, C.J., 2003. Glutathione content and the activities of glutathione-synthesizing enzymes in fission yeast are modulated by oxidative stress. Journal of Microbiology 41, 248-251.

Leroy, P., Nicolas, A., Wellmann, M., Michelet, F., Oster, T., Siest, G., 1993. Evaluation of $o$-phthalaldehyde as bifunctional fluorogenic post-column reagent for glutathione in LC. Chromatographia 36, 130-134.

Mathis, A., 2000. Microsporidia: emerging advances in understanding the basic biology of these unique organisms. International Journal for Parasitology 30, 795-804.

Mautner, S., Cool, K.A., Forbes, M.R., McCurdy, D.G., Dunn, A.M., 2007. Evidence for sex ratio distortion by a new microsporidian parasite of a Corophiid amphipod Parasitology 134, 1567-1573.

McCahon, C.P., Maund, S.J., Poulton, M.J., 1991. The effect of the acanthocephalan parasite (Pomphorhynchus laevis) on the drift of its intermediate host (Gammarus pulex). Freshwater Biology 25, 507-513.

Meister, A., 1983. Selective modification of glutathione metabolism. Science 220 $472-477$.

Méténier, G., Vivarès, C.P., 2001. Molecular characteristics and physiology of microsporidia. Microbes and Infection 3, 407-415.

Minguez, L., Meyer, A., Molloy, D.P., Giambérini, L., 2009. Interactions between parasitism and biological responses in zebra mussels (Dreissena polymorpha): importance in ecotoxicological studies. Environmental Research 109, 843-850.

Parmentier, C., Leroy, P., Wellman, M., Nicolas, A., 1998. Determination of cellula thiols and glutathione-related enzyme activities: versatility of highperformance liquid chromatography-spectrofluorimetric detection. Journal of Chromatography B: Biomedical Sciences and Applications 719, 37-46.
Pascoe, D., Kedwards, T.J., Blockwell, S.J., Taylor, E.J., 1995. Gammarus pulex (L.) feeding bioassay - Effects of parasitism. Bulletin of Environmental Contamination and Toxicology 55, 629-632.

Plaistow, S.J., Troussard, J.P., Cézilly, F., 2001. The effect of the acanthocephalan parasite Pomphorhynchus laevis on the lipid and glycogen content of its intermediate host Gammarus pulex. International Journal for Parasitology 31, 346-351.

Prenter, J., MacNeil, C., Dick, J.T.A., Riddell, G.E., Dunn, A.M., 2004. Lethal and sublethal toxicity of ammonia to native, invasive, and parasitised freshwater amphipods. Water Research 38, 2847-2850.

Ray, S., Misso, N.L.A., Lenzo, J.C., Robinson, C., Thompson, P.J., 1999. Gamma-glutamylcysteine synthetase activity in human lung epithelial (A549) cells: factors influencing its measurement. Free Radical Biology and Medicine 27, 1346-1356.

Rodgers-Gray, T.P., Smith, J.E., Ashcroft, A.E., Isaac, R.E., Dunn, A.M., 2004. Mechanisms of parasite-induced sex reversal in Gammarus duebeni. International Journal for Parasitology 34, 747-753.

Roesijadi, G., 1992. Metallothioneins in metal regulation and toxicity in aquatic animals. Aquatic Toxicology 22, 81-113.

Schlenk, D., Rice, C.D., 1998. Effect of zinc and cadmium treatment on hydrogen peroxide-induced mortality and expression of glutathione and metallothionein in a teleost hepatoma cell line. Aquatic Toxicology 43, 121-129.

Siddall, R., Sures, B., 1998. Uptake of lead by Pomphorhynchus laevis cystacanths in Gammarus pulex and immature worms in chub (Leuciscus cephalus). Parasitology Research 84, 573-577.

Singhal, R., Anderson, M., Meister, A., 1987. Glutathione, a first line of defense against cadmium toxicity. The FASEB Journal 1, 220-223.

Smith, J.E., 2009. The ecology and evolution of microsporidian parasites. Parasitology 136 (Special Issue 14), 1901-1914.

Soussi, M., Ouali, K., Hadj, M.W., Rouachdia, R., Djabouradi, A., Bensouilah, M., 2008. Proportioning of biomarkers (GSH, GST, AchE, catalase) indicator of pollution at Gambusia affinis (Teleostei fish) exposed to cadmium. Environmental Research Journal 2, 177-181.

Sparkes, T.C., Keogh, D.P., Pary, R.A., 1996. Energetic costs of mate guarding behavior in male stream-dwelling isopods. Oecologia 106, 166-171.

Sroda, S., Cossu-Leguille, C., 2011. Effects of sublethal copper exposure on two gammarid species: which is the best competitor? Ecotoxicology 20, 264-273. Stuhlbacher, A., Maltby, L., 1992. Cadmium resistance in Gammarus pulex (L.). Archives of Environmental Contamination and Toxicology 22, 319-324.

Sures, B., Taraschewski, H., 1995. Cadmium concentrations in two adult acanthocephalans, Pomphorhynchus laevis and Acanthocephalus lucii, as compared with their fish hosts and cadmium and lead levels in larvae of $A$. lucii as compared with their crustacean host. Parasitology Research 81, 494-497.

Sures, B., Siddall, R., Taraschewski, H., 1999. Parasites as accumulation indicators of heavy metal pollution. Parasitology Today 15, 16-21.

Sures, B., Scheef, G., Klar, B., Kloas, W., Taraschewski, H., 2002. Interaction between cadmium exposure and infection with the intestinal parasite Moniliformis moniliformis (Acanthocephala) on the stress hormone levels in rats. Environmental Pollution 119, 333-340.

Sures, B., 2004. Environmental parasitology: relevancy of parasites in monitoring environmental pollution. Trends in Parasitology 20, 170-177.

Sures, B., Thielen, F., Baska, F., Messerschmidt, J., von Bohlen, A., 2005. The intestinal parasite Pomphorhynchus laevis as a sensitive accumulation indicator for the platinum group metals Pt, Pd, and Rh. Environmental Research 98, 83-88.

Sures, B., Radszuweit, H., 2007. Pollution-induced heat shock protein expression in the amphipod Gammarus roeseli is affected by larvae of Polymorphus minutus (Acanthocephala). Journal of Helminthology 81, 191-197.

Terry, R.S., Smith, J.E., Dunn, A.M., 1998. Impact of a novel, feminising microsporidium on its crustacean host. Journal of Eukaryotic Microbiology 45, 497-501.

Terry, R.S., Smith, J.E., Sharpe, R.G., Rigaud, T., Littlewood, D.T.J., Ironside, J.E. Rollinson, D., Bouchon, D., MacNeil, C., Dick, J.T.A., Dunn, A.M., 2004. Widespread vertical transmission and associated host sex-ratio distortion within the eukaryotic phylum Microspora. Proceedings of the Royal Society of London. Series B: Biological Sciences 271, 1783-1789.

Thomas, P., Wofford, H.W., 1993. Effects of cadmium and Aroclor 1254 on lipid peroxidation, glutathione peroxidase activity, and selected antioxidants in Atlantic croaker tissues. Aquatic Toxicology 27, 159-177.

Timofeyev, M.A., Shatilina, Z.M., Kolesnichenko, A.V., Bedulina, D.S., Kolesnichenko, V.V., Pflugmacher, S., Steinberg, C.E., 2006. Natural organic matter (NOM) induces oxidative stress in freshwater amphipods Gammarus lacustris Sars and Gammarus tigrinus (Sexton). Science of the Total Environment 366, 673-681.

Timofeyev, M.A., Shatilina, Z.M., Bedulina, D.S., Protopopova, M.V., Pavlichenko, V.V., Grabelnych, O.I., Kolesnichenko, A.V., 2008. Evaluation of biochemical responses in Palearctic and Lake Baikal endemic amphipod species exposed to $\mathrm{CdCl}_{2}$. Ecotoxicology and Environmental Safety 70, 99-105.

Vasseur, P., Leguille, C., 2004. Defense systems of benthic invertebrates in response to environmental stressors. Environmental Toxicology 19, 433-436.

Vivarès, C.P., Martin, B.J., Ceccaldi, H.J., 1980. Acides gras de trois microsporidies (Protozoa) et de leur hôte Carcinus mediterraneus (Crustacea), sain et parasité par Thelohania maenadis. Parasitology Research 61, 99-107.

Vivarès, C.P., Cuq, J.L., 1981. Physiological and metabolic variations in Carcinus mediterraneus (Crustacea: Decapoda) parasitized by Thelohania maenadis (Microspora: Microsporida): an ecophysiopathological approach. Journal of Invertebrate Pathology 37, 38-46.

Wittner, M., Weiss, L.M., 1999. The Microsporidia and Microsporidiosis. American Society for Microbiology, Washington DC, USA, 553 pp. 